\title{
Clinical and Prognostic Significance of Neoplastic Spindle Cells in Gallbladder Cancer
}

\author{
RYUTA MIDORIKAWA ${ }^{1}$, TORU HISAKA ${ }^{1}$, HISAMUNE SAKAI ${ }^{1}$, YORIKO NOMURA ${ }^{1}$, \\ YUICHI GOTO ${ }^{1}$, TOSHIHIRO SATO ${ }^{1}$, RYUICHI KAWAHARA ${ }^{1}$, HIROTO ISHIKAWA ${ }^{1}$, \\ FUMIHIKO FUJITA $^{1}$, MASAFUMI YASUNAGA ${ }^{1}$, MASAHIKO TANIGAWA ${ }^{2}$, YOSHIKI NAITO ${ }^{2}$, \\ JUN AKIBA $^{2}$, HIROHISA YANO ${ }^{3}$, HIROYUKI TANAKA ${ }^{1}$, YOSHITO AKAGI ${ }^{1}$ and KOJI OKUDA ${ }^{1}$ \\ Departments of ${ }^{1}$ Surgery and ${ }^{3}$ Pathology, Faculty of Medicine, Kurume University, Kurume, Japan; \\ ${ }^{2}$ Department of Diagnostic Pathology, Kurume University Hospital, Kurume, Japan
}

\begin{abstract}
Background/Aim: Neoplastic spindle cells (NSCs) are believed to play a role in cancer invasion and metastasis, as well as in poor prognosis. The clinicopathological characteristics and prognostic relevance of NSCs was investigated in gallbladder cancer. Materials and Methods: Specimens were obtained from 62 patients with gallbladder cancer who underwent surgery. The emergence of NSCs and their correlation with clinicopathological factors, prognosis, and EMT markers was evaluated. Results: The NSC grade correlated with tumor size, preoperative CA19-9, surgical margin, the degree of differentiation, the depth of invasion, lymph node metastasis, lymphatic invasion, vascular invasion, and perineural invasion. Multivariate analysis of overall survival showed that NSCs were an independent prognostic factor. A correlation between NSCs and EMT was also suggested. Conclusion: NSCs are an independent prognostic factor for patients with postoperative gallbladder cancer, which also suggests a correlation between NSCs and EMT.
\end{abstract}

Gallbladder cancer is considered to be one of the most malignant forms of cancer for which chemotherapy and radiation therapy have little effect, and radical surgery remains the most effective treatment. The prognosis for patients with advanced gallbladder cancer is very poor, with a 5-year survival rate of $6-20 \%$ (1). The recurrence rate in these patients is quite high, and many patients develop distal

This article is freely accessible online.

Correspondence to: Toru Hisaka, MD, Ph.D., Department of Surgery, Kurume University Faculty of Medicine, 67 Asahi-machi, Kurume, Fukuoka 830-0011, Japan. Tel: +81 942317566, Fax: +81 942340709, e-mail: midorikawa_ryuuta@med.kurume-u.ac.jp

Key Words: Neoplastic spindle cells, gallbladder cancer, epithelialmesenchymal transition. metastases or experience local recurrence within 12 months of radical resection. In a recent histopathological study of gallbladder cancer, it was reported that the prognostic factors for patients with postoperative gallbladder cancer included the depth of invasion (T), lymph node metastasis $(\mathrm{N})$, the degree of tumor differentiation, the extent of surgical margin, lymphatic invasion (ly), and perineural invasion (pn) (2-8).

Neoplastic spindle cells (NSCs) are spindle-shaped cancer cells with no tubular structure (9). There have been reports suggesting that in conditions, such as pancreatic cancer, nasopharyngeal carcinoma, and vulvar squamous cell carcinoma, NSCs are associated with cancer invasion and metastasis and are factors for poor prognosis (10-12). It has also been suggested that changes in cell morphology, whereby epithelial cancer cells become spindle-shaped, may be a result of the cancer cells undergoing epithelial-mesenchymal transition (EMT), a process by which epithelial cells lose their polarity and cell-cell adhesion and gain migratory and invasive properties (10). It has been reported that when EMT is induced in epithelial cells, a decrease in E-cadherin expression and an increase in vimentin expression are observed $(13,14)$. Although it is conceivable that NSCs are found in highly malignant cancerous growth, to our knowledge, there are few reports on the characteristics of NSCs in gallbladder cancer, except for a few studies on the association between gallbladder cancer and EMT (15-18).

In this study, we investigated the clinicopathological characteristics of NSCs and their correlation with postoperative survival of patients in whom gallbladder cancer was treated using surgical resection.

\section{Materials and Methods}

Patient background and method of tissue collection. In total, 62 patients who were diagnosed with gallbladder cancer and underwent surgical resection (but not R2 resection) between 2006 and 2016 at the Kurume University Hospital, Fukuoka, Japan, were chosen for this study. 
Resected specimens were fixed with $10 \%$ neutral buffered formalin. The specimens were then cut into 5- $\mu$ m thick slices, stained with hematoxylin and eosin (H\&E), and observed under a microscope. Histopathological findings were evaluated in accordance with the TNM Classification of Malignant Tumours (8th Edition) of the Union for International Cancer Control (UICC) (19), by two pathologists who had no knowledge of the clinical characteristics of the patients involved. In cases the evaluations of the two pathologists were different, a reevaluation was conducted until a consensus could be reached. We collected the clinical data and information from follow-up consultations using medical records and the Cancer Database. This study was conducted with the approval of the Kurume University Ethics Review Board (Approval No. 17326).

Evaluation of NSCs. We defined spindle-shaped cancer cells or cancer cells with oval nuclei and no tubular structure as NSCs. Typical NSCs are shown in Figure 1. Using the H\&E stained specimens, the sites that showed the most prominent transition into NSCs in or surrounding the tumor were evaluated. The specimens were assigned one of three grades as follows according to the proportion of NSCs: Grade 0, NSCs <10\%; Grade 1, 10\%-50\% NSCs; and Grade 2, NSCs $>50 \%$.

Assessment of E-cadherin and vimentin. Formalin-fixed, paraffinembedded sections of $5 \mu \mathrm{m}$ thickness were mounted on glass slides and incubated with anti-rabbit monoclonal antibody against vimentin (Clone V9, dilution: 1:9, DAKO, Santa Clara, CA, USA) and E-cadherin (clone NCH-38 dilution: 1:100, DAKO), and assessments of these two proteins were conducted using the same fully automated Bond-III system (Leica Microsystems) with onboard heat-induced antigen retrieval solution 1 for $10 \mathrm{~min}$ at $99^{\circ} \mathrm{C}$ for vimentin and with epitope retrieval solution 2 for $30 \mathrm{~min}$ at room temperature for E-cadherin. This automated system used a polymer refine detection kit with a horseradish peroxidase-polymer as a secondary antibody and 3,3-diaminobenzidine. The tissues were incubated with the secondary antibody for $30 \mathrm{~min}$ at room temperature.

To assess the levels of E-cadherin and vimentin, we studied the specimens that had shown high proportion of NSCs after $H \& E$ staining. The results of the E-cadherin assessment were considered positive when $10 \%$ or more of the cancer cell membranes were stained, whereas the results of vimentin assessments were considered positive when $10 \%$ or more of the cancer cell cytoplasm was stained, as reported by Kim et al. (20).

Statistical analyses. The correlation between NSC grade and clinicopathological factors, namely NSCs occurrence and Ecadherin/vimentin expression was analyzed using Fisher's exact test. Using the Cox proportional hazards model, univariate and multivariate analyses were conducted to identify the negative prognostic factors. Overall survival time refers to the period between the date of surgery and the last follow-up date or date of death. The Kaplan-Meier method was used to calculate the cumulative survival rate. The log-rank test was used to compare the survival rate between the groups having two different levels of NSCs detected. $p<0.05$ was set as the level of significance. The data were analyzed using JMP v. 13 (SAS Institute, Tokyo, Japan).
Table I. Clinicopathological characteristics of patients with gallbladder cancer $(N=62)$.

\begin{tabular}{|c|c|c|}
\hline Characteristics & Patients & $\%$ \\
\hline \multicolumn{3}{|l|}{ Age (years) } \\
\hline Range & \multicolumn{2}{|l|}{$41-86$} \\
\hline Median & \multicolumn{2}{|l|}{71} \\
\hline \multicolumn{3}{|l|}{ Gender } \\
\hline Male & 28 & $45.2 \%$ \\
\hline Female & 34 & $54.8 \%$ \\
\hline \multicolumn{3}{|c|}{ Tumor size $(\mathrm{mm})$} \\
\hline Median & \multicolumn{2}{|c|}{29} \\
\hline Range & \multicolumn{2}{|c|}{$10-90$} \\
\hline \multicolumn{3}{|l|}{$\mathrm{CEA}(\mathrm{ng} / \mathrm{ml})$} \\
\hline Median & \multicolumn{2}{|c|}{2.4} \\
\hline Range & \multicolumn{2}{|c|}{$0.5-50.5$} \\
\hline \multicolumn{3}{|l|}{ CA19-9 (ng/ml) } \\
\hline Median & \multicolumn{2}{|c|}{17.8} \\
\hline Range & \multicolumn{2}{|c|}{$0.8-315.8$} \\
\hline \multicolumn{3}{|l|}{ Surgical margin } \\
\hline R0 & 54 & $87.1 \%$ \\
\hline $\mathrm{R} 1$ & 8 & $12.9 \%$ \\
\hline \multicolumn{3}{|c|}{ Complication $\geq$ CD IIIa } \\
\hline Absent & 55 & $88.7 \%$ \\
\hline Present & 7 & $11.2 \%$ \\
\hline \multicolumn{3}{|l|}{ Differentiation } \\
\hline Pap & 28 & $45.2 \%$ \\
\hline Well & 20 & $32.3 \%$ \\
\hline Mode & 6 & $9.7 \%$ \\
\hline Poor & 4 & $6.5 \%$ \\
\hline Other & 4 & $6.5 \%$ \\
\hline \multicolumn{3}{|l|}{$\mathrm{T}$ category } \\
\hline Tis & 9 & $14.5 \%$ \\
\hline $\mathrm{T} 1$ & 8 & $12.9 \%$ \\
\hline $\mathrm{T} 2$ & 32 & $51.6 \%$ \\
\hline $\mathrm{T} 3$ & 12 & $19.4 \%$ \\
\hline $\mathrm{T} 4$ & 1 & $1.6 \%$ \\
\hline \multicolumn{3}{|l|}{$\mathrm{N}$ category } \\
\hline No & 51 & $82.3 \%$ \\
\hline N1 & 10 & $16.1 \%$ \\
\hline N2 & 0 & $0 \%$ \\
\hline $\mathrm{Nx}$ & 1 & $1.6 \%$ \\
\hline \multicolumn{3}{|c|}{ Lymphatic invasion } \\
\hline- & 33 & $53.2 \%$ \\
\hline+ & 29 & $46.8 \%$ \\
\hline \multicolumn{3}{|c|}{ Vascular invasion } \\
\hline- & 38 & $61.3 \%$ \\
\hline+ & 24 & $38.7 \%$ \\
\hline \multicolumn{3}{|c|}{ Perineural invasion } \\
\hline- & 44 & $71.0 \%$ \\
\hline+ & 18 & $29.0 \%$ \\
\hline Stage & & \\
\hline Stage 0 & 9 & $14.5 \%$ \\
\hline Stage I & 7 & $11.3 \%$ \\
\hline Stage II & 25 & $40.3 \%$ \\
\hline Stage III & 19 & $30.6 \%$ \\
\hline Stage IV & 1 & $1.6 \%$ \\
\hline
\end{tabular}

CD: Clavien-Dindo Classification; pap: papillary adenocarcinoma; well: well differentiated tubular adenocarcinoma; mode: moderately differentiated tubular adenocarcinoma; poor: poorly differentiated adenocarcinoma. 
Table II. Correlation between clinicopathological characteristics and NSC grades in patients with gallbladder cancer.

\begin{tabular}{|c|c|c|c|c|c|}
\hline Characteristics & Total & NSCs0 & NSCs 1 & NSCs2 & $p$-Value* \\
\hline \multicolumn{6}{|l|}{ Age (mean, 71) } \\
\hline$\leq 70$ & 27 & 14 & 6 & 7 & \multirow[t]{2}{*}{0.21} \\
\hline$>70$ & 35 & 26 & 4 & 5 & \\
\hline \multicolumn{6}{|l|}{ Gender } \\
\hline Male & 28 & 19 & 5 & 4 & \multirow[t]{2}{*}{0.75} \\
\hline Female & 34 & 21 & 5 & 8 & \\
\hline \multicolumn{6}{|l|}{ Tumor size (mm) } \\
\hline$\leq 30$ & 33 & 26 & 4 & 3 & \multirow{2}{*}{0.013} \\
\hline$>30$ & 26 & 11 & 6 & 9 & \\
\hline \multicolumn{6}{|l|}{$\mathrm{CEA}(\mathrm{ng} / \mathrm{ml})$} \\
\hline$\leq 5$ & 50 & 35 & 7 & 8 & \multirow[t]{2}{*}{0.078} \\
\hline$>5$ & 11 & 4 & 3 & 4 & \\
\hline \multicolumn{6}{|l|}{ CA19-9 (ng/ml) } \\
\hline$\leq 37$ & 48 & 34 & 7 & 11 & \multirow[t]{2}{*}{0.030} \\
\hline$>37$ & 13 & 5 & 5 & 1 & \\
\hline \multicolumn{6}{|c|}{ Complication $\geq$ CD IIIa } \\
\hline absent & 55 & 37 & 7 & 11 & \multirow[t]{2}{*}{0.11} \\
\hline present & 7 & 3 & 3 & 1 & \\
\hline \multicolumn{6}{|l|}{ Surgical margin } \\
\hline R0 & 54 & 39 & 6 & 9 & \multirow[t]{2}{*}{0.0017} \\
\hline $\mathrm{R} 1$ & 8 & 1 & 4 & 3 & \\
\hline \multicolumn{6}{|l|}{ Differentiation } \\
\hline Pap, well & 48 & 38 & 5 & 5 & \multirow[t]{2}{*}{$<0.001$} \\
\hline Mode, poor, other & 14 & 2 & 5 & 7 & \\
\hline \multicolumn{6}{|l|}{$\mathrm{T}$ category } \\
\hline Tis, T1, T2 & 49 & 40 & 4 & 5 & \multirow[t]{2}{*}{$<0.001$} \\
\hline $\mathrm{T} 3, \mathrm{~T} 4$ & 13 & 0 & 6 & 7 & \\
\hline \multicolumn{6}{|l|}{$\mathrm{N}$ category } \\
\hline No & 51 & 36 & 9 & 6 & \multirow[t]{2}{*}{0.028} \\
\hline N1 & 10 & 4 & 1 & 5 & \\
\hline \multicolumn{6}{|l|}{ Lymphatic invasion } \\
\hline- & 33 & 29 & 2 & 2 & \multirow[t]{2}{*}{$<0.001$} \\
\hline+ & 29 & 11 & 8 & 10 & \\
\hline \multicolumn{6}{|l|}{ Vascular invasion } \\
\hline- & 38 & 32 & 3 & 3 & \multirow[t]{2}{*}{$<0.001$} \\
\hline+ & 24 & 8 & 7 & 9 & \\
\hline \multicolumn{6}{|l|}{ Perineural invasion } \\
\hline- & 44 & 37 & 5 & 2 & \multirow[t]{2}{*}{$<0.001$} \\
\hline+ & 18 & 3 & 5 & 10 & \\
\hline
\end{tabular}

NSCs: Neoplastic spindle cells; CD: Clavien-Dindo Classification; pap: papillary adenocarcinoma; well: well differentiated tubular adenocarcinoma; mode: moderately differentiated tubular adenocarcinoma; poor: poorly differentiated adenocarcinoma. *Using the Fisher's exact test.

\section{Results}

The clinicopathological factors of 62 patients with gallbladder cancer. The median age was 71 years, and $55 \%$ of the patients were female. The median tumor size was 29 $\mathrm{mm} \quad$ (range $=10-90 \mathrm{~mm}$ ), median preoperative carcinoembryonic antigen (CEA) was $2.4 \mathrm{ng} / \mathrm{ml}$ (range $=0.5$ $50.5 \mathrm{ng} / \mathrm{ml}$ ), and the median preoperative cancer antigen (CA) $19-9$ was $17.8 \mathrm{ng} / \mathrm{ml}$ (range=0.8-315.8 ng/ml). Among all patients, 8 (13\%) underwent $\mathrm{R} 1$ resection. The ClavienDindo Grade IIIa classification or above for surgical complications (21) was observed in seven patients. Most patients were diagnosed with papillary adenocarcinoma or well-differentiated adeno-carcinoma, and "three patients with adenosquamous carcinoma and 1 with squamous cell carcinoma. There were nine patients with an invasion depth of Tis, 8 with T1, 32 with T2, 12 with T3, and 1 with T4. Further, ly was positive in 29 patients $(46.8 \%)$, vascular invasion (v) was positive in 24 patients $(38.7 \%)$, pn was positive in 18 patients $(29.0 \%)$, and $\mathrm{N} 1$ was observed in 10 patients $(16.1 \%)$. With regard to the UICC TNM classifications, there were nine patients with Stage 0, seven with Stage I, 25 with Stage II, 19 with Stage III, and one with Stage IV (Table I). 
Table III. Univariate and multivariate analyses of the overall survival of patients after surgery.

\begin{tabular}{|c|c|c|c|c|c|c|c|}
\hline \multirow[b]{2}{*}{ Characteristics } & \multirow[b]{2}{*}{ Patients total } & \multicolumn{3}{|c|}{ Univariate Analysis* } & \multicolumn{3}{|c|}{ Multivariate Analysis* } \\
\hline & & $p$-Value & HR & $95 \% \mathrm{CI}$ & $p$-Value & HR & $95 \% \mathrm{CI}$ \\
\hline \multicolumn{8}{|l|}{ Age (years) } \\
\hline$\leq 70$ & 27 & 0.34 & & & & & \\
\hline$>70$ & 35 & & & & & & \\
\hline \multicolumn{8}{|l|}{ Gender } \\
\hline Male & 28 & 0.71 & & & & & \\
\hline Female & 34 & & & & & & \\
\hline \multicolumn{8}{|l|}{ Tumor size (mm) } \\
\hline$\leq 30$ & 33 & 0.15 & & & & & \\
\hline$>30$ & 26 & & & & & & \\
\hline \multicolumn{8}{|l|}{ CEA (ng/ml) } \\
\hline$\leq 5$ & 50 & 0.11 & & & & & \\
\hline$>5$ & 11 & & & & & & \\
\hline \multicolumn{8}{|l|}{ CA19-9 (ng/ml) } \\
\hline$\leq 37$ & 48 & 0.82 & & & & & \\
\hline$>37$ & 13 & & & & & & \\
\hline \multicolumn{8}{|l|}{ Complication $\geq$ CD IIIa } \\
\hline Absent & 55 & 0.68 & & & & & \\
\hline Present & 7 & & & & & & \\
\hline \multicolumn{8}{|l|}{ Surgical margin } \\
\hline R0 & 54 & 0.002 & 7.08 & $2.26-18.65$ & 0.007 & 8.73 & $1.88-38.64$ \\
\hline $\mathrm{R} 1$ & 8 & & & & & & \\
\hline \multicolumn{8}{|l|}{ Differentiation } \\
\hline Pap, well & 48 & 0.093 & & & & & \\
\hline Mode, poor, other & 14 & & & & & & \\
\hline \multicolumn{8}{|l|}{$\mathrm{T}$ category } \\
\hline Tis, T1, T2 & 49 & 0.045 & 2.69 & $1.02-6.38$ & 0.20 & & \\
\hline $\mathrm{T} 3, \mathrm{~T} 4$ & 13 & & & & & & \\
\hline \multicolumn{8}{|l|}{$\mathrm{N}$ category } \\
\hline No & 51 & 0.004 & 4.56 & $1.68-11.39$ & 0.68 & & \\
\hline N1 & 10 & & & & & & \\
\hline \multicolumn{8}{|l|}{ Lymphatic invasion } \\
\hline- & 33 & 0.007 & 3.19 & $1.36-8.31$ & 0.078 & & \\
\hline+ & 29 & & & & & & \\
\hline \multicolumn{8}{|l|}{ Vascular invasion } \\
\hline- & 38 & 0.033 & 2.48 & $1.08-5.75$ & 0.21 & & \\
\hline+ & 24 & & & & & & \\
\hline \multicolumn{8}{|l|}{ Perinural invasion } \\
\hline- & 44 & $<0.001$ & 5.16 & $2.22-12.12$ & 0.034 & 4.87 & $1.13-19.51$ \\
\hline+ & 18 & & & & & & \\
\hline \multicolumn{8}{|l|}{ NSCs } \\
\hline NSCs low (grade 0 , grade 1 ) & 50 & $<0.001$ & 10.35 & $3.93-28.13$ & 0.005 & 6.65 & $1.74-30.43$ \\
\hline NSCs high (grade 2) & 12 & & & & & & \\
\hline
\end{tabular}

NSCs: Neoplastic spindle cells; CD: Clavien-Dindo Classification; pap: papillary adenocarcinoma; well: well differentiated tubular adenocarcinoma; mode: moderately differentiated tubular adenocarcinoma; poor: poorly differentiated adenocarcinoma; HR: hazard ratio; CI: confidence interval. *Using the Cox proportional hazards model.

Correlation between NSC grade and clinicopathological factors. Totally, 40 patients (64.5\%) had NSC Grade 0, 10 (16.1\%) Grade 1, and 12 (19.3\%) Grade 2. These grades showed a statistically significant correlation with tumor size ( $p=0.013)$, preoperative CA19-9 $(p=0.030)$, surgical margin $(p=0.0017)$, differentiation $(p<0.001)$, T category $(p<0.001)$, $\mathrm{N}$ category $(p=0.028)$, ly $(p<0.001), \mathrm{v}(p<0.001)$, and $\mathrm{pn}$ $(p<0.001)$ (Table II).
Survival rate analysis based on NSCs and clinicopathological factors. The patients were divided into two groups according to NSC grade as follows: the low NSCs group (Grades 0 and 1) and the high NSCs group (Grade 2). Univariate analysis of overall survival after surgical resection showed that the prognostic factors with a significant difference were surgical margin, T category, $\mathrm{N}$ category, ly, $\mathrm{v}, \mathrm{pn}$, and NSCs. Multivariate analyses of these factors using 


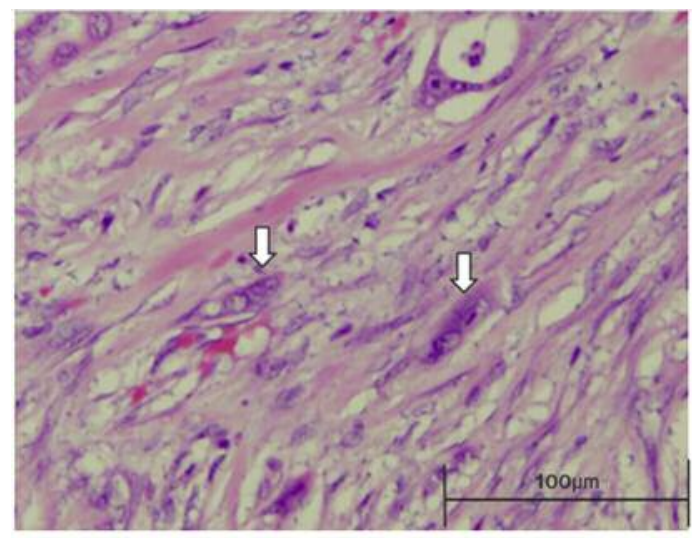

Figure 1. Photomicrograph of NSCs. Spindle-shaped cancer cells or cancer cells with oval nuclei and no tubular structure (White arrow). NSCs: Neoplastic spindle cells.

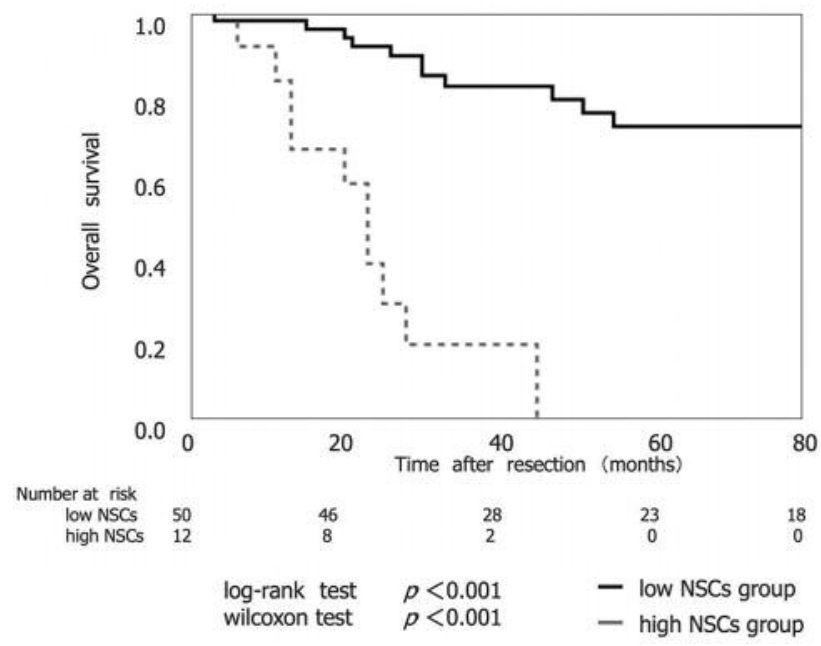

Figure 2. The survival rate between the low NSCs and the high NSCs groups using the Kaplan-Meier method. The 5-year survival rate of the low NSCs group was $72.2 \%$ and that of the high NSCs group was $0 \%$. The difference in survival rates between the two groups was significant (log-rank test, $p<0.001)$. NSCs: Neoplastic spindle cells.

them as covariates showed that the independent prognostic factors after surgery for patients with gallbladder cancer were surgical margin [hazard ratio (HR), 8.73; 95\% confidence interval $(\mathrm{CI})=1.88-38.64 ; \quad p=0.007]$, pn $(\mathrm{HR}=4.87 ; 95 \% \mathrm{CI}=1.13-19.51 ; \quad p=0.034)$, and NSCs $(\mathrm{HR}=6.65 ; 95 \% \mathrm{CI}=1.74-30.43 ; p=0.005)$ (Table III).

Comparison of survival rate between low and high NSCs groups. We compared the survival rates between the low NSCs and high NSCs groups using the Kaplan-Meier method. The 5-year survival rate of the low NSCs group was
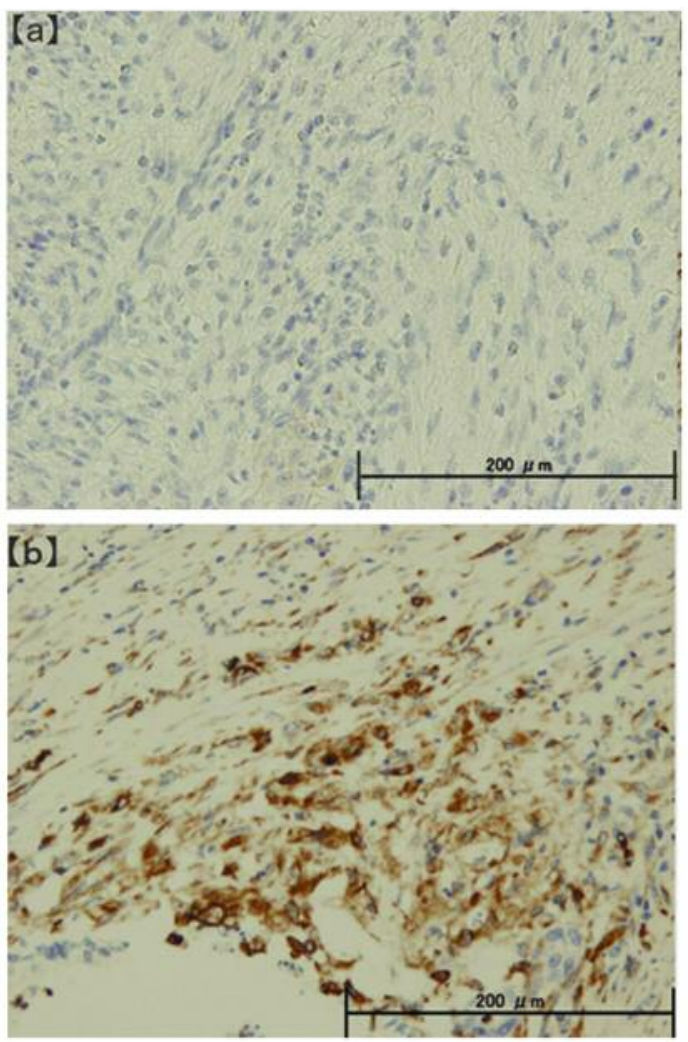

Figure 3. Immunostaining of NSCs. (a) E-cadherin immunostaining was negative, (b) vimentin immunostaining was positive $(\times 200)$. Evaluation of E-cadherin/vimentin expression in gallbladder cancer cells. NSCs: Neoplastic spindle cells.

$72.2 \%$ and that of the high NSCs group was $0 \%$. The difference in survival rates between the two groups was significant (log-rank test, $p<0.001$ ) (Figure 2).

Correlation between NSC grade and E-cadherin/vimentin expression. The E-cadherin-negative group (Figure 3a) comprised 0 patients with NSC Grade 0,1 with Grade 1, and 9 with Grade 2, whereas the vimentin-positive group (Figure 3 b) comprised 0 patients with Grade 0,3 with Grade 1 , and 12 with Grade 2. NSC grade and E-cadherin expression negatively correlated with each other, whereas NSC grade and vimentin expression positively correlated with each other; both correlations were statistically significant $(p<0.001)$ (Table IV).

\section{Discussion}

We conducted a clinicopathological evaluation of NSCs found in specimens taken from patients with gallbladder cancer who underwent surgical resection, and observed that 
Table IV. Correlation between NSC grades and E-cadherin/vimentin expression.

\begin{tabular}{|c|c|c|c|c|c|}
\hline & Total & NSCs0 & NSCs1 & NSCs2 & $p$-Value* \\
\hline All patients & 62 & 40 & 10 & 12 & \\
\hline \multicolumn{6}{|l|}{ E-cadherin } \\
\hline Negative & 10 & 0 & 1 & 9 & $p<0.001$ \\
\hline Positive & 52 & 40 & 9 & 3 & \\
\hline \multicolumn{6}{|l|}{ Vimentin } \\
\hline Negative & 47 & 40 & 7 & 0 & $p<0.001$ \\
\hline Positive & 15 & 0 & 3 & 12 & \\
\hline
\end{tabular}

NSCs: Neoplastic spindle cells. *Using the Fisher's exact test.

the NSC grades significantly correlated with tumor size, preoperative CA19-9, the extent of surgical margin, the degree of differentiation, the depth of invasion (T), lymph node metastasis (N), lymphatic invasion (ly), vascular invasion (v), and perineural invasion ( $\mathrm{pn}$ ). We also analyzed the overall survival with respect to NSCs and 13 other factors that are considered to be major prognostic factors for gallbladder cancer, such as $\mathrm{T}$ category and $\mathrm{N}$ category. Among those factors, the high NSCs grade had a strong impact on overall survival with an HR of 6.65 , which was the highest following R0 resection revealing that NSCs are an independent prognostic factor that affects the overall survival after surgery in patients with gallbladder cancer. The 5-year survival rate was $72.2 \%$ in the low NSCs group and $0 \%$ in the high NSCs group, which suggests an extremely poor prognosis for those with high NSCs grade. It has been reported that there is a correlation between NSCs and tumor size, TNM stage, $\mathrm{N}$, histological grade, invasion to the pancreatic nerve plexus, duodenal invasion, invasion to retroperitoneal tissue, $1 \mathrm{y}$, and venous invasion in patients with pancreatic cancer, and that NSCs are an independent prognostic factor for disease-free and overall survival (12). It has also been reported that NSCs show a correlation with the stage and lymph node metastasis of vulvar squamous cell carcinoma, which suggests that they are independent prognostic factor (11). In light of the above, it is suggested that there is a possibility that NSCs have a strong influence on gallbladder cancer invasion and proliferation and are one of the major prognostic factors for patients with this cancer who undergo surgical resection.

The expression of molecular markers that accompany EMT in relation to NSCs in patients with gallbladder cancer was also evaluated. During the EMT process, embryonic epithelial cells lose their polarity and cell-cell adhesion and gain migratory and invasive properties to become mesenchymal stem cells. Cancer cells are known to induce EMT (22) and, when induced, the adhesion between epithelial cells is weakened, the cytoskeleton is restructured, and the morphology changes from flat and scalelike into spindle-shaped cells (23-25). Molecules that are known to be related to EMT include E-cadherin, which is one of the epithelial markers involved in cell-cell adhesion, and vimentin, which is a mesenchymal cell marker involved in cytoskeletal interactions $(13,26)$. Increased expression of E-cadherin and decreased expression of vimentin is observed in cancer cells undergoing EMT resulting in an acceleration of migration and invasion capabilities of the cancer cells (27). This study also showed that NSCs in tumors negatively correlated with Ecadherin and positively correlated with vimentin. This suggests the possibility that in gallbladder cancer an EMT mechanism operates that has a negative impact on the biological malignancy. In patients with nasopharyngeal carcinoma, a significant decrease in E-cadherin expression and an increase in vimentin expression have been observed, along with an increased expression of snail and slug, which are transcription factors that play a central role in EMT (10). In association with gallbladder cancer, it has been reported that vimentin showed correlation with gallbladder cancer metastasis and had a strong influence on cancer progression (28). Given these findings, we suggest that there is a strong correlation between NSCs and EMT in gallbladder cancer. Moreover, the evaluation of NSCs is useful in formulating a prognosis after surgery for patients with gallbladder cancer, and may be used to determine the course of postoperative adjuvant therapy.

There were some problems associated with evaluating NSCs using H\&E staining, one of which was that it is difficult to determine the three-dimensional structure of specimens when they are prepared on slides, and at times cancer cells that have transitioned into NSCs appear as ordinary cancer cells because of the way in which the specimens have been sliced. A second problem was that there is the possibility that cancer tissues contain cells at various stages of EMT, which means that some cells have not yet completed their morphological changes into NSCs. Although the evaluation of NSCs using H\&E staining appears to be an important step in considering a prognosis, the development of more accurate methods to evaluate these cells is required.

In conclusion, NSCs influence the invasion and proliferation of gallbladder cancer cells and are an independent prognostic 
factor for patients with gallbladder cancer who undergo surgical resection. Additionally, there is a possibility that NSCs are cancer cells in which EMT has been induced. We suggest that NSCs can be included in the evaluation criteria used for the prognosis of patients with highly malignant gallbladder cancer.

\section{Conflicts of Interest}

The Authors declare no conflicts of interest associated with this manuscript.

\section{Authors' Contributions}

Ryuta Midorikawa designed the study, and wrote the initial draft of the manuscript. Ryuta Midorikawa and Toru Hisaka contributed to analysis and interpretation of data, and assisted in the preparation of the manuscript. All other authors contributed to data collection and interpretation, and critically reviewed the manuscript. All authors approved the final version of the manuscript, and agreed to be accountable for all aspects of the work in ensuring that questions related to the accuracy or integrity of any part of the work are appropriately investigated and resolved.

\section{Acknowledgements}

The Authors are grateful to all patients and their families for providing the opportunity to conduct the present research project. The authors wish thank Dr. T. Kakuma and Dr. Z. Ozawa for helpful discussion and advice about statistical analysis. The Authors also thanks Ms. M. Toyofuku for continuing support.

\section{References}

1 Miyakawa S, Ishihara S, Horiguchi A, Takada T, Miyazaki M and Nagakawa T: Biliary tract cancer treatment: 5,584 results from the Biliary Tract Cancer Statistics Registry from 1998 to 2004 in Japan. J Hepatobiliary Pancreat Surg 16(1): 1-7, 2009. PMID: 19110652. DOI: 10.1007/s00534-008-0015-0

2 Varga M, Obrist P, Schneeberger S, Mühlmann G, FelgelFarnholz C, Fong D, Zitt M, Brunhuber T, Schäfer G, Gastl G and Spizzo G: Overexpression of epithelial cell adhesion molecule antigen in gallbladder carcinoma is an independent marker for poor survival. Clin Cancer Res 10(9): 3131-3136, 2004. PMID: 15131054.

3 Shimada H, Endo I, Togo S, Nakano A, Izumi T and Nakagawara $\mathrm{G}$ : The role of lymph node dissection in the treatment of gallbladder carcinoma. Cancer 79(5): 892-899, 1997. PMID: 9041150.

4 Ito $\mathrm{H}$, Ito $\mathrm{K}$, D'Angelica M, Gonen M, Klimstra D, Allen P, DeMatteo RP, Fong Y, Blumgart LH and Jarnagin WR: Accurate staging for gallbladder cancer: implications for surgical therapy and pathological assessment. Ann Surg 254(2): 320-325, 2011 PMID: 21617582. DOI: 10.1097/SLA.0b013e31822238d8

5 Shibata K, Uchida H, Iwaki K, Kai S, Ohta M and Kitano S: Lymphatic invasion: an important prognostic factor for stages T1b-T3 gallbladder cancer and an indication for additional radical resection of incidental gallbladder cancer. World J Surg 33(5): 1035-1041, 2009. PMID: 19225832. DOI: 10.1007/ s00268-009-9950-4
6 Yamaguchi R, Nagino M, Oda K, Kamiya J, Uesaka K and Nimura Y: Perineural invasion has a negative impact on survival of patients with gallbladder carcinoma. Br J Surg 89(9): 11301136, 2002. PMID: 12190678. DOI: 10.1046/j.1365-2168.2002. 02184.X

7 Shirai Y, Yoshida K, Tsukada K, Muto T and Watanabe H: Radical surgery for gallbladder carcinoma. Long-term results. Ann Surg 216(5): 565-568,1992. PMID: 1359844. DOI: 10.1097/00000658-199211000-00007

8 Dixon E, Vollmer CM Jr, Sahajpal A, Cattral M, Grant D, Doig C, Hemming A, Taylor B, Langer B, Greig P and Gallinger S: An aggressive surgical approach leads to improved survival in patients with gallbladder cancer: a 12-year study at a North American Center. Ann Surg 241(3): 385-394, 2005. PMID: 15729060. DOI: 10.1097/01.sla.0000154118.07704.ef

9 Hassanein MK, Suetsugu A, Saji S, Moriwaki H, Bouvet M, Moossa AR and Hoffman RM: Stem-like and non-stem human pancreatic cancer cells distinguished by morphology and metastatic behavior. J Cell Biochem 112(12): 3549-3554, 2011. PMID: 21780159 . DOI: $10.1002 /$ jcb.23282

10 Luo WR, Chen XY, Li SY, Wu AB and Yao KT: Neoplastic spindle cells in nasopharyngeal carcinoma show features of epithelial-mesenchymal transition. Histopathology 61(1): 113122, 2012. PMID: 22486228. DOI: 10.1111/j.1365-2559.2012. 04205.x

11 Trietsch MD, Peters AA, Gaarenstroom KN, van Koningsbrugge SH, ter Haar NT, Osse EM, Halbesma N and Fleuren GJ: Spindle cell morphology is related to poor prognosis in vulvar squamous cell carcinoma. Br J Cancer 109(8): 2259-2265, 2013. PMID: 24064972. DOI: 10.1038/bjc.2013.563

12 Takahashi K, Hisaka T, Horiuchi H, Ishikawa H, Nakayama M, Nakashima O, Kawahara A, Kage M, Yano H, Akagi Y, Yonemoto K, Kinoshita H and Shirouzu K: Neoplastic spindle cells are an independent prognostic factor in pancreatic cancer. Pancreas 44(5): 742-749, 2015. PMID: 25931259. DOI: 10. 1097/MPA.0000000000000337

13 Micalizzi DS, Farabaugh SM and Ford HL: Epithelialmesenchymal transition in cancer: parallels between normal development and tumor progression. J Mammary Gland Biol Neoplasia 15(2): 117-134, 2010. PMID: 20490631. DOI: 10.1007/s10911-010-9178-9

14 Ceausu AR, Ciolofan A, Cimpean AM, Magheti A, Mederle O and Raica M: The mesenchymal-epithelial and epithelialmesenchymal cellular plasticity of liver metastases with digestive origin. Anticancer Res 38(2): 811-816, 2018. PMID: 29374706. DOI: 10.21873 /anticanres. 12288

15 Puhalla H, Herberger B, Soleiman A, Filipits M, Laengle F, Gruenberger $\mathrm{T}$ and Wrba $\mathrm{F}$ : E-cadherin and beta-catenin expression in normal, inflamed and cancerous gallbladder tissue. Anticancer Res 25(6): 4249-4254, 2005. PMID: 16309224.

16 Zhang M, Gong W, Zhang Y, Yang Y, Zhou D, Weng M, Qin Y, Jiang A, Ma F and Quan Z: Expression of interleukin-6 is associated with epithelial-mesenchymal transition and survival rates in gallbladder cancer. Mol Med Rep 11(5): 3539-3546, 2015. PMID: 25573292. DOI: $10.3892 / \mathrm{mmr} .2014 .3143$

17 Xiong L, Wen Y, Miao X and Yang Z: Expressions of cell junction regulatory proteins and their association with clinicopathologic parameters in benign and malignant gallbladder lesions. Am J Med Sci 342(5): 388-394, 2011. PMID: 22033073. DOI: 10.1097/MAJ.0b013e31821e12af 
18 Sasaki T, Kuniyasu H, Luo Y, Kato D, Shinya S, Fujii K, Ohmori $\mathrm{H}$ and Yamashita Y: Significance of epithelial growth factor in the epithelial-mesenchymal transition of human gallbladder cancer cells. Cancer Sci 103(6): 1165-1171, 2012. PMID: 22404757. DOI: 10.1111/j.1349-7006.2012.02264.x

19 Brierley J, Gospodarowicz MK and Wittekind CH: TNM classification of malignant tumours. 8th edition. Chichester, West Sussex, UK; Hoboken, NJ: John Wiley \& Sons, Inc. 2017.

$20 \mathrm{Kim}$ MA, Lee HS, Lee HE, Kim JH, Yang HK and Kim WH: Prognostic importance of epithelial-mesenchymal transition-related protein expression in gastriccarcinoma. Histopathology 54(4): 442451, 2009. PMID: 19309396. DOI: 10.1111/j.1365-2559.2009. 03247.x

21 Dindo D, Demartines N and Clavien PA: Classification of surgical complications: a new proposal with evaluation in a cohort of 6336 patients and results of a survey. Ann Surg 240(2): 205-213, 2004. PMID: 15273542. DOI: 10.1097/01.sla.0000133083.54934.ae

22 Thiery JP, Acloque H, Huang RY and Nieto MA: Epithelialmesenchymal transitions in development and disease. Cell 139(5): 871-890, 2009. PMID: 19945376. DOI: 10.1016/j.cell.2009.11.007

23 Shirakihara T, Saitoh M and Miyazono K: Differential regulation of epithelial and mesenchymal markers by deltaEF1 proteins in epithelial mesenchymal transition induced by TGF-beta. Mol Biol Cell 18(9): 3533-3544, 2007. PMID: 17615296. DOI: 10.1091/ mbc.e07-03-0249

24 Ye X and Weinberg RA: Epithelial-mesenchymal plasticity: a central regulator of cancer progression. Trends Cell Biol 25(11): 675-686, 2015. PMID: 26437589. DOI: 10.1016/j.tcb.2015.07.012
25 Ellenrieder V, Hendler SF, Boeck W, Seufferlein T, Menke A, Ruhland C, Adler G and Gress TM: Transforming growth factor beta1 treatment leads to an epithelial-mesenchymaltrans differentiation of pancreatic cancer cells requiring extracellular signal-regulated kinase 2activation. Cancer Res 61(10): 42224228, 2001. PMID: 11358848.

26 Tsoukalas N, Aravantinou-Fatorou E, Tolia M, Giaginis C, Galanopoulos M, Kiakou M, Kostakis ID, Dana E, Vamvakaris I, Korogiannos A, Tsiambas E, Salemis N, Kyrgias G, Karameris A and Theocharis S: Epithelial-mesenchymal transition in non-smallcell lung cancer. Anticancer Res 37(4): 1773-1778, 2017. PMID: 28373440. DOI: 10.21873/anticanres.11510

27 Taylor MA, Parvani JG and Schiemann WP: The pathophysiology of epithelial-mesenchymal transition induced by transforming growth factor-beta in normal and malignant mammary epithelial cells. J Mammary Gland Biol Neoplasia 15(2): 169-190, 2010. PMID: 20467795. DOI: 10.1007/s10911-010-9181-1

28 Dong P, He XW, Gu J, Wu WG, Li ML, Yang JH, Zhang L, Ding QC, Lu JH, Mu JS, Chen L, Li SG, Ding LF, Wang JW and Liu YB: Vimentin significantly promoted gallbladder carcinoma metastasis. Chin Med J (Engl) 124(24): 4236-4244, 2011. PMID: 22340393. 